\title{
Phosphorus fractionation in volcanic lake sediments (Azores - Portugal)
}

\author{
D.C. Ribeiro ${ }^{\text {a }}$, G. Martins ${ }^{\text {a }}$, R. Nogueira ${ }^{\text {a }}$, J.V. Cruz ${ }^{\text {b }}$, A.G. Brito ${ }^{\text {a,* }}$ \\ ${ }^{a}$ Institute for Biotechnology and Bioengineering, Centre for Biological Engineering - University of Minho, DEB, \\ Campus de Gualtar 4700-057 Braga, Portugal \\ ${ }^{\mathrm{b}}$ Geosciences Department - University of Azores (currently at Regional Department of Water Resources and Land Planning), Portugal
}

Received 6 March 2007; received in revised form 19 July 2007; accepted 26 July 2007

Available online 14 September 2007

\begin{abstract}
The phosphorus distribution in volcanic sediments of three lakes that are under different anthropogenic pressures in São Miguel island (Azores - Portugal) was evaluated using a sequential extraction scheme. The P-fractionation scheme employs sequential extractions of sediment with $\mathrm{NH}_{4} \mathrm{Cl}$, bicarbonate-dithionite (BD), $\mathrm{NaOH}$ (at room temperature), $\mathrm{HCl}$ and $\mathrm{NaOH}$ (at $85^{\circ} \mathrm{C}$ ) to obtain five $\mathrm{P}$-fractions. The P-fractionation shows that in lakes with higher trophic status (Lake Furnas and Lake Sete Cidades), the NaOH extracted $\mathrm{P}$ is the dominant fraction, that contribute with more than 50\% to total sedimentary phosphorus. The rank order of P-fractionation for these two lakes was $\mathrm{NaOH}>\mathrm{NaOH}\left(85^{\circ} \mathrm{C}\right)>\mathrm{HCl}>\mathrm{BD}>\mathrm{NH}_{4} \mathrm{Cl}$ for Furnas lake and $\mathrm{NaOH}>\mathrm{HCl}>\mathrm{NaOH}\left(85^{\circ} \mathrm{C}\right)>\mathrm{NH}{ }_{4} \mathrm{Cl}>\mathrm{BD}$ for $\mathrm{Sete}$ Cidades lake. On the other hand, the trend of $\mathrm{P}$ contribution in the oligotrophic lake Fogo shows that the most inert $\mathrm{P}$ pools have the higher concentrations, with more than $50 \%$ of the $\mathrm{P}$ contribution from the last extraction step with $\mathrm{NaOH}$ at $85{ }^{\circ} \mathrm{C}$. For this lake, the rank order of $\mathrm{P}$-fractionation was $\mathrm{NH}_{4} \mathrm{Cl}>\mathrm{BD}>\mathrm{NaOH}>\mathrm{HCl}>\mathrm{NaOH}\left(85^{\circ} \mathrm{C}\right)$. The Phosphorus Maximum Solubilization Potential (P-MSP) was also calculated and the results show that for the more bio-available P-fractions (first and second extraction step), the P-MSP values for Furnas and Sete Cidades lakes are sensibly higher than the results obtained in Fogo lake, an indication of the non-point diffuse load discharged in the first ones.
\end{abstract}

(C) 2007 Elsevier Ltd. All rights reserved.

Keywords: Eutrophication; Phosphorus extraction; Sediment; Volcanic lakes

\section{Introduction}

Biological productivity in lakes is strongly related to the concentration of phosphorus $(\mathrm{P})$ in the water column. It has been shown that the sediment of the lakes can act as an internal source of phosphorus for the overlying water (Lijklema et al., 1993; Ramm and Scheps, 1997; Zhou et al., 2001). This is especially important when the external nutrient sources are controlled. In this context, many studies in the past years have been made to understand the factors that affect the $\mathrm{P}$ release from the sediments. Temperature, redox reactions, $\mathrm{pH}$, dissolved oxygen concentration, nitrate, sulfates and bacterial activity are pointed as the major controlling factors (Kim et al., 2003; Jin et al., 2006).

\footnotetext{
${ }^{*}$ Corresponding author. Tel.: +351 253604 400; fax: +351 253678986 . E-mail address: agbrito@deb.uminho.pt (A.G. Brito).
}

Phosphorus is present in sediments in several chemical forms (Gonsiorczyk et al., 1998). Thus, prediction of future internal P-loading requires more than the knowledge on the total concentration of phosphorus. Soil P-fractionation has been investigated since 1957 and later applied to lake sediments to overcome the limited information that total$\mathrm{P}$ analysis can provide (Zhou et al., 2001). Since then, several procedures for phosphorus extraction in sediments have been proposed in order to suit studies of different sediment mineral phases. (Psenner and Pucsko, 1988; Ruttenberg, 1992; Ruban et al., 1999). These sequential extraction schemes made possible, in several studies, to characterize the diverse forms in which $\mathrm{P}$ is distributed in sediments, classified as labile $\mathrm{P}$, reductant $\mathrm{P}$, metal bound $\mathrm{P}$, occluded $\mathrm{P}$ and organic $\mathrm{P}$ (Psenner and Pucsko, 1988). These fractions have been also classified as water soluble $\mathrm{P}$, readily desorbable $\mathrm{P}$, algal available $\mathrm{P}$ or ecologically important P (Pettersson et al., 1988; Zhou et al., 2001). 
The aim of this research is to define $\mathrm{P}$ speciation and profile in the sediments of three lakes, in São Miguel, as a tool for understanding the potential mobility of $\mathrm{P}$ from sediments to the overlaying water and corresponds to the first study to apply phosphorus speciation to characterize in these lake sediments. In the present study we used a modified Psenner sheme (Psenner and Pucsko, 1988), as already proposed by Romero-González (Romero-Gonzalez et al., 2001). This procedure allows the partial separation of $\mathrm{P}$ iron-bond fraction from aluminum and calcium-bond fraction.

\section{Material and methods}

\subsection{Study site}

The three studied lakes are located in the island of São Miguel which belongs to the archipelago of Azores (Portugal), located between the parallels $36^{\circ} 45^{\prime}-39^{\circ} 43^{\prime}$ of latitude North and meridians $24^{\circ} 45^{\prime}-31^{\circ} 17^{\prime}$ of longitude West (Fig. 1). The eutrophic shallow lake Furnas is located in East side of the island. The Sete Cidades lake is located in the Western part of São Miguel and it is composed by two interconnected lakes, the so-called Azul and Verde lakes. The Azul lake is at meso-eutrophic state but the Verde lake is already classified as eutrophic. The third studied lake is Fogo, an oligo-mesotrophic lake, located in the central part of the island. The morphometric and geochemical characteristics of the lakes are presented in Table 1.

The three studied lakes are in the bottom of large calderas, located in the three volcanic centers that dominated São Miguel geology. These centers correspond to the major active trachytic central volcanoes of Fogo, Sete Cidades and Furnas, linked by rift zones. During the last 5000 years the activity of these three active central volcanoes is shown by 57 volcanic eruptions, with an output of $4.6 \mathrm{~km}^{3}$ of dense rock (Booth et al., 1978). For the whole island of São Miguel it is possible to estimate an overall erupted volume of $400 \mathrm{~km}^{3}$ in the past four million years, at an average volume of at least $0.01 \mathrm{~km}^{3}$ per century. The majority of these eruptions presented were explosive, resulting in pumice deposits, of acid character, that cover the volcanoes flanks. Therefore, in the bottom of the lakes it is expected that sediments present a close relation with these pumice
Table 1

Physical and Chemical properties of the studied lakes

$\begin{array}{ll}\text { Lake Furnas } & \begin{array}{l}\text { Lake Sete } \\ \text { Cidades }\end{array}\end{array}$

Physical description $^{\mathrm{b}}$
Surface Area $\left(\mathrm{km}^{2}\right)$

Max. Depth (m)

Volume $\left(\mathrm{m}^{3}\right)$

Volcanic setting

1.9

12

9212500

Caldera

Chemical and trophic parameters ${ }^{\mathrm{a}}$

$\mathrm{pH}^{\mathrm{b}} \quad 7.36$

$\mathrm{EC}\left(\mu \mathrm{S} \mathrm{cm}^{-1}\right)^{\mathrm{b}}$

$\mathrm{HCO}_{3}\left(\mathrm{mg} \mathrm{l}^{-1}\right)^{\mathrm{b}}$

$\mathrm{Ca}\left(\mathrm{mg} \mathrm{l}^{-1}\right)^{\mathrm{b}}$

Dissolved $\mathrm{CO}_{2}\left(\mathrm{mg} \mathrm{l}^{-1}\right)^{\mathrm{b}}$

$\mathrm{NO}_{3}^{-}\left(\mathrm{mg} \mathrm{l}^{-1}\right)$

$\mathrm{SO}_{4}^{2-}\left(\mathrm{mg} \mathrm{l}^{-1}\right)$

Soluble reactive

Total phosphorus $\left(\mu \mathrm{g}^{-1}\right)^{\mathrm{c}}$

Chla $\left(\mathrm{mg} \mathrm{m}^{-3}\right)^{\mathrm{c}}$

Secchi disc transparency $(\mathrm{m})^{\mathrm{c}}$

Trophic classification
$\mathrm{Mg}\left(\mathrm{mg} \mathrm{l}^{-1}\right)^{\mathrm{b}}$ phosphorus $\left(\mu \mathrm{g} \mathrm{P}^{-1}\right)^{\mathrm{c}}$
7.36
142.78

49.01

2.88

2.27

10.33

1.04

22.7

11

45

17.85

0.8

Hypertrophic
4.35

33

$47760500 \quad 18040800$

Caldera

Caldera

$\begin{array}{ll}7.46 & 6.68\end{array}$

$113.67 \quad 47.50$

$28.28 \quad 6.20$

$1.32 \quad 0.80$

$\begin{array}{ll}5.98 & 2.97\end{array}$

$1.33 \quad 0.42$

$10.2 \quad 12.1$

3

21

10.43

2.3

2.73

$-$

MesoEutrophic
$1.43 \quad 0.48$

\footnotetext{
${ }^{a}$ Variation can occur by seasonal changes.

b Data from Cruz and França (2006).

${ }^{\mathrm{c}}$ Data from water monitoring network from regional government.
}

deposits. Thus the granulometry analysis shown that the finer fraction (silt and clay) is dominant and it corresponds to $98 \%$ of the sediment composition, of which silt is the main class.

São Miguel Island is also called "The Green Island" which definitely is its dominant colour, due to the fact that the area is occupied by highly fertilized grass fields crossed by small rivers of not constant flow. Their flows depend mostly on the rainfall which is often very intense leading to significant soil erosion and to the discharge of nutrients from the grass fields into the lakes.

Besides the nutrient input due to agriculture, secondary manifestations of active volcanism may also contribute to water composition in these studied lakes, through seepage of thermal waters or gaseous compounds. At the fumaroles

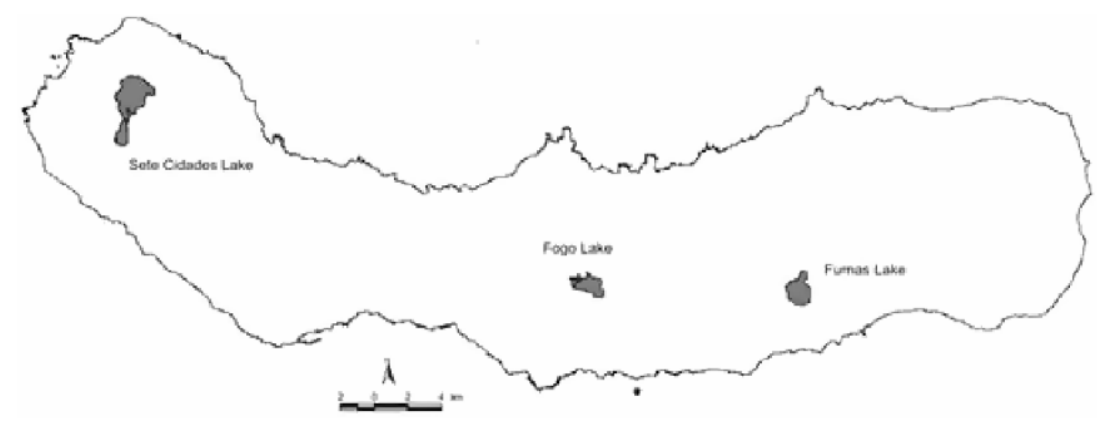

Fig. 1. Location of the studied lakes in S. Miguel Island. 
field located in the north margin of Furnas lake the discharge of boiling $\mathrm{SO}_{4}$-rich waters occurs convicted to a steam-heating mechanism (Cruz and França, 2006) and in the field surface runoff to the lake is observable. Therefore it is not excluded that these steam-heated waters are a supplementary $\mathrm{SO}_{4}$ source into the lake.

\subsection{Water/sediment sampling and analysis}

One sediment sample was collected in February 2006, at the deepest locations of each of the three lakes. For the Sete Cidades Lake, the core was made in the deepest site of the Verde lake. A gravitational Uwitec-corer was used, which enabled collecting undisturbed sediment cores, in the soft sediments of the studied lakes. The Uwitec-corer tubes, with a diameter of $60 \mathrm{~mm}$, and $600 \mathrm{~mm}$ length, had penetrated about $220-440 \mathrm{~mm}$ in the sediments, and collected also the overlaying water. The sediment samples with the water were sealed in situ, in the core tubes. After a very delicate transportation into the laboratory, the water from the sampling core tubes was recovered, sealed in glass flasks and preserved at $4{ }^{\circ} \mathrm{C}$ until the analysis. The sediment of each core tube was cut in five slices with an Uwitec Mechanical cutting apparatus. Each slice was homogenized, dried at $105^{\circ} \mathrm{C}$, sealed and conserved frozen in plastic Petri dishes, until the analysis.

\subsubsection{Water analysis}

The analyzed chemical parameters of the water were phosphate $\left(\mathrm{PO}_{4}^{3-}\right)$, nitrate $\left(\mathrm{NO}_{3}^{-}\right)$, and sulfate $\left(\mathrm{SO}_{4}^{2-}\right)$, after filtration with a $0.45 \mu \mathrm{m}$ membrane. Phosphate was analyzed by spectrophotometric method by the molybdenum blue/stannous chloride method, nitrate by ultraviolet spectrophotometric screening method, and sulfate by turbidimetric method (APHA et al., 1995).

\subsubsection{Phosphorus fractionation}

The phosphorus fractionation method used in the present work was the Psenner and Pucsko (1988) scheme, with minor modifications. This extraction method draws the conclusion on the P-binding forms in the sediments (Table 2), and is also useful to predict bioavailability of $\mathrm{P}$.

After each extraction step, samples were centrifuged at $7000 \mathrm{rpm}$, for $20 \mathrm{~min}$., and the supernatant was filtrated through a $0.45 \mu \mathrm{m}$ membrane. The analysis of SRP was made by molybdenum blue/stannous chloride method (APHA et al., 1995). The total-P (TP) analysis was achieved by an acid digestion of the samples, with nitric and sulfuric acids at $250^{\circ} \mathrm{C}$, and further analyzed as a SRP sample. The NRP fraction is defined as the difference between TP and SRP. With this extraction procedure, as shown in Table 2, phosphorus is fractionated in labile $\mathrm{P}\left(\mathrm{NH}_{4} \mathrm{Cl}\right)$, redox-sensitive $\mathrm{P}$ (bicarbonate-dithionite), metal oxide bound $\mathrm{P}$ (NaOH-SRP), organically bound $\mathrm{P}(\mathrm{NaOH}-\mathrm{NRP}), \mathrm{Ca}-$ bound $\mathrm{P}(\mathrm{HCl})$, refractory/residual $\mathrm{P}$ (hot $\mathrm{NaOH})$.

\subsection{Phosphorus maximum solubilization potential $(P-M S P)$ : definition and presumptions}

We define phosphorus Maximum solubilization potential (P-MSP) as a hypothetical concentration of phosphorus in the water column, in the case of total dissolution of the $\mathrm{P}$ present in the sediments, for each chemical form. Naturally, this hypothetical event is extremely improbable, as it depends on many complex chemical and biological processes. However, the purpose of this calculation is to estimate the maximum input limit of $\mathrm{P}$ from the sediments to the overlaying water.

This theoretical parameter is calculated from the results of $\mathrm{P}$ concentration obtained by the sequential extraction procedure applied in the sediments of the studied lakes. For this evaluation, several presumptions have been assumed:

- All the sediment area of the lake has the same environmental conditions as well as the same phosphorus chemical forms concentration.

- A water and sediment control volume is defined and all the lakes' water body and sediments have the same physical and chemical behavior of the respective control volumes.

Table 2

Extraction procedure used in the present work, adapted from Psenner and Pucsko (1988) extraction scheme (SRP - Soluble Reactive Phosphorus; NRP - Non Reactive Phosphorus; TP - Total Phosphorus)

\begin{tabular}{|c|c|c|c|}
\hline Step & Solvent & P-Fraction & P bounding forms \\
\hline 1 & $\mathrm{NH}_{4} \mathrm{Cl}$ & SRP & $\begin{array}{l}\text { Loosely bound P: Pore water soluble phosphate and sediment surface loosely adsorbed } \\
\text { phosphate, algal available phosphate }\end{array}$ \\
\hline 2 & $\begin{array}{l}\mathrm{BD}(0.11 \mathrm{M})(\text { Bicarbonate }- \\
\text { Dithionite) } 40^{\circ} \mathrm{C}\end{array}$ & $\begin{array}{l}\text { SRP } \\
\text { NRP }\end{array}$ & $\begin{array}{l}\text { Reductant soluble P: Redox-sensitive P, mainly bound to Fe-hydroxide and Mn-hydroxide } \\
\text { Redox-sensitive organic P }\end{array}$ \\
\hline 3 & $\begin{array}{l}\mathrm{NaOH}(1 \mathrm{M})(\text { Sodium } \\
\text { Hydroxide }) 40^{\circ} \mathrm{C}\end{array}$ & SRP & $\begin{array}{l}\text { Metallic oxide bound P: Phosphate bound to metallic oxide (mainly } \mathrm{Fe} \text { and } \mathrm{Al} \text { ), soluble } \\
\text { inorganic } \mathrm{P} \text { compounds in alkaline solution }\end{array}$ \\
\hline & & NRP & $\mathrm{P}$ in micro-organisms, detritus, humic compounds, poly-P, P-lipid \\
\hline 5 & $\mathrm{NaOH}(1 \mathrm{M}) 85^{\circ} \mathrm{C}$ & $\mathrm{TP}$ & Organic refractory $\mathrm{P}$ \\
\hline
\end{tabular}


- Only vertical diffusion of $\mathrm{P}$ is considered and the water column is homogeneous (no thermal or chemical gradients).

- The sediment control volume is homogeneous with a mean concentration value for each the $P$ forms, calculated by the results obtained in the $\mathrm{P}$-fractionation procedure.

Only the values at approximately $50 \mathrm{~mm}$ depth have been used for the determination of the mean $\mathrm{P}$ concentration in the sediments.

The control volumes for each sediment and water column have the same area, which is the one made by the corer in the sediments. Therefore, the control volume $V \mathrm{c}_{i}$ for each sediment ( $i=$ sed) or water column ( $i=$ wat) is cylindrical, with a circular base area $(A)$. The length of the cylindrical control volume for the sediments $(h)$ considered was $50 \mathrm{~mm}$. This means that, for all this $50 \mathrm{~mm}$ length control volume, the sediment is homogeneous and has $\mathrm{P}$ concentration equal to the mean value calculated from the results of P-fractionation. For the water body, the length of the control volume $(H)$ depends on the length of the deepest location of the lake (Table 1). The Eqs. (1) and (2) shows the calculation of the control volume for the sediments and water column.

$V c_{\text {sed }}=A \times h=\frac{\pi}{4} d^{2} \times h$
$V c_{\text {wat }}=A \times H=\frac{\pi}{4} d^{2} \times H$

The density $\left(\rho_{\text {sed }}\right)$ and porosity $(\phi)$ of the sediments are $2.439 \mathrm{~kg} \mathrm{l}^{-1}$ and 0.90 , respectively. The control volume of the sediments $\left(V \mathrm{c}_{\mathrm{sed}}\right)$ is the sum of the sediments volume $\left(V_{\text {sed }}\right)$ and volume occupied by the interstitial water $\left(V_{\mathrm{w}_{\text {sed }}}\right)$ present in the sediments (Eq. (3)). With the combination of Eqs. (3) and (4) we can obtain the sediments volume (Eq. (5)).

$$
\begin{aligned}
& V_{\text {sed }}=V c_{\text {sed }}-V w_{\text {sed }} \Longleftrightarrow V w_{\text {sed }}=V c_{\text {sed }}-V_{\text {sed }} \\
& \phi=\frac{V w_{\text {sed }}}{V c_{\text {sed }}} \\
& V_{\text {sed }}=V c_{\text {sed }} \cdot(1-\phi)
\end{aligned}
$$

The exact sediment mass $\left(m_{\text {sed }}\right)$ can be calculated by multiplying the sediment volume and the sediment density, as demonstrated by the Eq. (6). With the results of $\mathrm{P}$ concentration in the sediments $\left(C_{\mathrm{P}, \mathrm{sed}}\right)$ obtained in the applied sequential extraction procedure and with the calculated sediment volume, we can determine the $\mathrm{P}$ mass present in the sediment $\left(m_{\mathrm{P}, \mathrm{sed}}\right)$, for each P chemical forms (Eq. (7)).

$$
\begin{aligned}
& m_{\text {sed }}=\rho_{\text {sed }} \cdot \frac{\pi}{4} \cdot d^{2} \cdot h \cdot(1-\phi) \\
& m_{\mathrm{P}, \text { sed }}=C_{\mathrm{P}, \text { sed }} \cdot m_{\text {sed }} \\
& \text { P-MSP }=\frac{m_{\mathrm{P}, \text { sed }}}{V_{\text {wat }}}=\frac{C_{\mathrm{P}, \text { sed }} \cdot m_{\text {sed }}}{\frac{\pi}{4} \cdot d^{2} \cdot H} \\
& \text { P-MSP }=\frac{C_{\mathrm{P}, \text { sed }} \cdot \rho_{\text {sed }} \cdot \frac{\pi}{4} \cdot d^{2} \cdot h \cdot(1-\phi)}{\frac{\pi}{4} \cdot d^{2} \cdot H} \\
& \text { P-MSP }=\frac{C_{\mathrm{P}, \text { sed }} \cdot \rho_{\text {sed }} \cdot h \cdot(1-\phi)}{H}
\end{aligned}
$$

The concentration of $\mathrm{P}$ in the water control volume, if hypothetically all the $\mathrm{P}$ mass from the sediment control volume would dissolve into it, is given by the Eq. (8), and represents the P-MSP theoretical parameter. The results of P-MSP for each lake and $\mathrm{P}$ forms are presented in Table 3.

\section{Results}

\subsection{Water at the interface}

Despite the fact that several chemical parameters were analyzed, the most important in the present work is the phosphate analysis. As so, the results for the water analysis will focus only in the soluble phosphate concentration.

The SRP concentration in the sediments' overlaying water for Fogo, Furnas and Sete Cidades core site was 24,17 and $47 \mu \mathrm{g} \mathrm{P} 1^{-1}$, respectively. The highest SRP concentration is found in Sete Cidades lake. In contrast of what would be expected, hypereutrophic lake Furnas has the lowest concentration of SRP. Lake Fogo has a slightly higher concentration than Lake Furnas, although Fogo is at lower trophic status.

\subsection{Sediment}

Although TP analyses for each step were performed, in the present work only SRP analysis results will be showed and further discussed. The main reason is that this work is specially focused in a geochemical approach. Therefore, these results are the most accurate for the assessment of bioavailability of $\mathrm{P}$, in a chemical point-of-view. Further work in a more biological approach will be made, and NRP pool (which is mainly organic P) will be considered,

\begin{tabular}{|c|c|c|c|c|c|}
\hline & $\mu \mathrm{g} \mathrm{P} 1^{-1}$ & & & & \\
\hline & NH4Cl-SRP & BD-SRP & $\mathrm{NaOH}-\mathrm{SRP} 45^{\circ} \mathrm{C}$ & HCl-SRP & $\mathrm{NaOH}-\mathrm{SRP} 85^{\circ} \mathrm{C}$ \\
\hline Fogo & $1.0( \pm 0.2)$ & $2.2( \pm 0.9)$ & $8.6( \pm 5.6)$ & $9.2( \pm 1.6)$ & $19.5( \pm 3.6)$ \\
\hline
\end{tabular}
as well as specific biological processes of degradation. The results are next presented for each lake.

\subsubsection{Lake Fogo}

The mean value of the sum of SRP concentration, for all extraction steps (and depth) is $86 \mu \mathrm{g} \mathrm{P} \mathrm{g}^{-1} \mathrm{dw}$. However,

Table 3

Values of P-MSP for each lake and P extracted form (in brackets are the standard deviation values) 


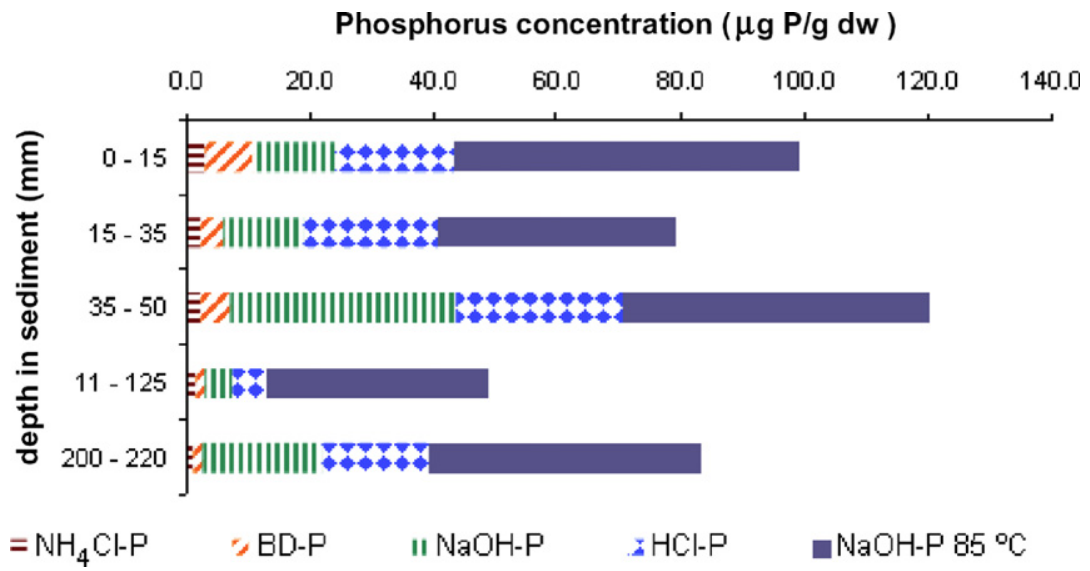

Fig. 2. Phosphorus fractionation in sediments from Lake Fogo.

the distribution of $\mathrm{P}$ in sediments is not linear, as the higher amount of SRP is located in the first $50 \mathrm{~mm}$ of the studied sediment core (Fig. 2).

For all the samples, the major part of the phosphorus has been extracted in step 5 , with $\mathrm{NaOH}$ at $85^{\circ} \mathrm{C}$. The most bio-available $\mathrm{P}$, which is extracted in the fist step $\left(\mathrm{NH}_{4} \mathrm{Cl}-\mathrm{P}\right)$, is present at low concentration in the sediment of this lake $\left(2 \mu \mathrm{g} \mathrm{P} \mathrm{g}^{-1} \mathrm{dw}\right)$.

The $\mathrm{P}$ bound to Fe-hydroxide and Mn-hydroxide (BDextraction step) is also in low concentration $\left(4 \mu \mathrm{g} \mathrm{P} \mathrm{g}^{-1}\right.$ $\mathrm{dw})$, in comparison with the other extraction steps. Results also demonstrate that in loosely bound $\mathrm{P}$ and redox-sensitive $\mathrm{P}$ (extracted in the first two steps), SRP is more concentrated at the upper part of the sediment, decreasing with depth.

\subsubsection{Lake furnas}

In Furnas Lake, the mean SRP concentration in the analyzed samples is $325 \mu \mathrm{g} \mathrm{P} \mathrm{g}{ }^{-1} \mathrm{dw}$, which is almost four times higher comparing to Lake Fogo. In this case, the most extracted $\mathrm{P}$ was verified in the third step $(\mathrm{NaOH})$. The fifth step, also performed with $\mathrm{NaOH}$ (at $85^{\circ} \mathrm{C}$ ), highly contribute to the sedimentary phosphorus $(54.2 \%)$.
Thus, both extractions with $\mathrm{NaOH}$ which extracts the $\mathrm{P}$ bound to oxide metals (mainly $\mathrm{Fe}$ and $\mathrm{Al}$ ) and organic $\mathrm{P}$ compounds have major contribution $(80.9 \%)$ in the sediments from this lake (Fig. 3).

The loosely bound $\mathrm{P}$ is almost constant along the core, and has a relatively low concentration $\left(6 \mu \mathrm{g} \mathrm{P}^{-1}\right)$. The BD-P concentration reaches his maximum in the middle of the sediment core, but still in relatively low concentration $\left(12 \mu \mathrm{g} \mathrm{P} 1^{-1}\right)$. The HCl-P contribution shows it to be more or less constant along the analyzed core.

\subsubsection{Lake Sete Cidades (Verde Lake)}

The sediment P-fractionation of the Verde lake, shows that the extraction step that most contributed to $\mathrm{P}$ concentration was the cold $\mathrm{NaOH}$ extraction (third step). The loosely bound P-fraction has higher concentrations in the upper sediment zone (interface zone), as shown in Fig. 4. The $\mathrm{P}$ contribution by the $\mathrm{NH}_{4} \mathrm{Cl}, \mathrm{HCl}$ and hot $\mathrm{NaOH}$ extraction steps is similar (Fig. 5).

The mean concentration of SRP of the sum of all extractions (for all samples), is $228 \mu \mathrm{g} \mathrm{g} \mathrm{g}^{-1} \mathrm{dw}$ in this lake. The higher SRP concentration is observable in $195-210 \mathrm{~mm}$ depth interval (262 $\mu \mathrm{g} \mathrm{P} \mathrm{g}^{-1} \mathrm{dw}-$ Fig. 4).

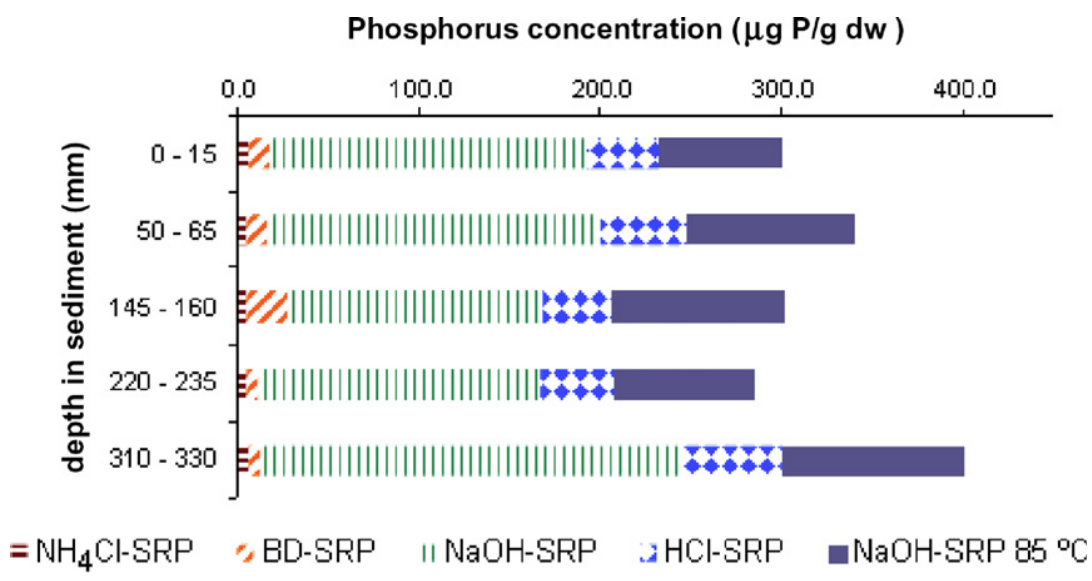

Fig. 3. Phosphorus fractionation in sediments from Lake Furnas. 


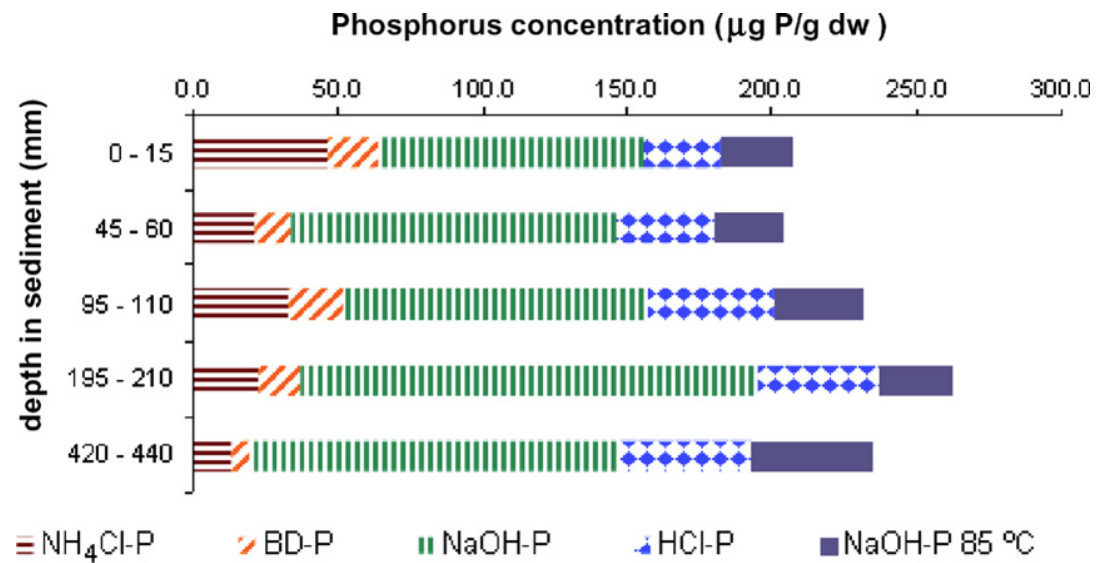

Fig. 4. Phosphorus fractionation in sediments from Lake Sete Cidades.

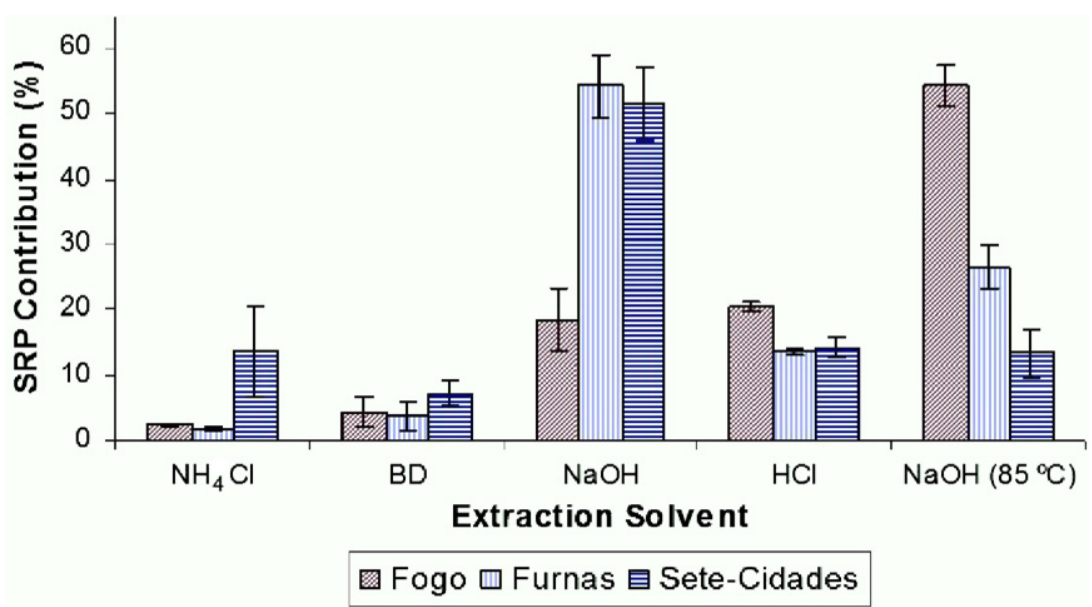

Fig. 5. Relative contribution of each extraction step to sedimentary phosphorus (mean values and standard deviation of the five studied samples of sediment core).

\subsection{Phosphorus maximum solubilization potential}

The P-MSP results are demonstrated in Table 3 with the maximum values for each lake in bold type and the standard deviation in brackets. Fogo lake has the higher $\mathrm{P}$ potential in the fifth extraction step $\left(\mathrm{NaOH}\right.$ at $\left.85^{\circ} \mathrm{C}\right)$ while Furnas and Sete Cidades lake show to have the $\mathrm{P}$ higher potential in the third one $(\mathrm{NaOH})$.

\section{Discussion}

\subsection{Loosely adsorbed phosphorus $\left(\mathrm{NH}_{4} \mathrm{Cl}-\mathrm{P}\right)$}

The immediately available $\mathrm{P}$ in sediments corresponds mostly to soluble inorganic $\mathrm{P}$, which is mainly orthophosphate. Therefore, the loosely adsorbed $\mathrm{P}$ (also called water soluble phosphorus - WSP) is the best parameter for assessment of bioavailability of $\mathrm{P}$ (Zhou et al., 2001). Analytical results suggest that NH4Cl-P concentration in Sete Cidades lake is between 59 and $13 \mu \mathrm{g} \mathrm{P} \mathrm{g}^{-1} \mathrm{dw}$, with the higher values in the upper sediment layers. In comparison with the other two lakes, Sete Cidades has the higher con- centration value of NH4Cl-P. This means that loosely adsorbed $\mathrm{P}$ will be easily available to algae, promoting consequent blooms. The SRP concentration in the sediment's overlaying water is also higher in Lake Sete Cidades. A comparison between the Fogo and Furnas lake in terms of NH4Cl-P extraction shows that Furnas has concentrations 2.3-5.4 times higher than Fogo. The decrease of the NH4Cl-P concentration with depth, for the three lakes, might be explained by the decrease of $\mathrm{pH}$ with depth, which enhance desorption of P (Gonsiorczyk et al., 1998).

\subsection{Reductant soluble phosphorus (BD-P)}

The reductant SRP is assumed to be bound to Fe-hydroxide and Mn compounds. For all the studied lakes, this form of $\mathrm{P}$ is present in relatively low concentrations (Fig. 5). For Lake Sete Cidades reductant $\mathrm{P}$ is the smallest contributor for the total amount of SRP. Nevertheless, when the hypolimnium is in reductive state, due to low oxygen concentration, this P-metal hydroxide bound might be released. However, the widely accepted hypothesis of phosphate release from anoxic sediments due to $\mathrm{Fe}(\mathrm{OOH})-\mathrm{P}$ complex 
reduction has been questioned (Golterman, 2001). Golterman (2001) has also shown by calculation (for an hypothetical shallow lake) of the reduction capacity, that the BD-P contribution from the sediments to the overlaying water is low, and that small changes in $\mathrm{Fe}(\mathrm{OOH})$ concentration will have no impact in P release (Golterman, 2001). Further work over samples collected along the present study, including specific rate flux calculation, will be done to investigate the role of BD-P pool in the eutrophication problem.

\subsection{Metallic oxide bound phosphorus (NaOH-P)}

The concentration of $\mathrm{P}$ bound to $\mathrm{Fe}$ and $\mathrm{Al}$ oxides is much higher in the two eutrophic lakes that in the Lake Fogo (oligo-to-mesotrophic). The NaOH-P amount in Lake Furnas is about six times higher than Lake Fogo. This extraction step is the major contributor to SRP concentration for both Lake Furnas and Sete Cidades (Fig. 5). Lake Furnas has also the highest concentration of dissolved iron in the water $\left(241 \mu \mathrm{g}^{-1}\right.$ at deepest site, and an average of $100 \mu \mathrm{g}^{-1}$ ) of all the three lakes, as shown by Cruz and França (2006). Therefore, Lake Furnas presents the highest value of $\mathrm{NaOH}-\mathrm{P}$ concentration. It has been shown that $\mathrm{NaOH}$ extractable $\mathrm{P}$ is significantly correlated with 2-days and 14-days available $P$ for an alga named Selenastrum capricornutum (Zhou et al., 2001). This specie is present in some lakes in the Azores archipelago, but has not been identified in the studied lakes. However, several species from de Selenastrum sp. gender are now included in the Ankistrodesmus sp. and Monoraphidium sp. genders. In the Furnas and Sete Cidades lakes, several species form the Ankistrodesmus sp. and Monoraphidium sp. genders were identified. This means that, the $\mathrm{NaOH}-\mathrm{P}$ could be available for these algal species. The $\mathrm{NaOH}$ extractable $\mathrm{P}$ has also been suggested to be used for estimation of short and long-term available $P$ in the sediment, and is a measure of algal available phosphorus (Zhou et al., 2001). In this context, we can say that, both Lake Furnas and Sete Cidades have a highly potential available $\mathrm{P}$ for algae, which is undesirable for the eutrophication control.

As shown by Xiangcan Jin et al. (2006), NaOH-P might be released by the change of $\mathrm{pH}$ to higher values. In this case, $\mathrm{pH}$ control is very important, as this is the main potential pool for P-release in the studied lakes. However, this extraction step has been criticized because it seems that it is not so specific for metallic oxide bound $\mathrm{P}$, as it is claimed to be. Golterman (2001) has shown that phosphate extraction with $\mathrm{NaOH}$ is time and concentration dependent and will also extract phytate phosphate and org-P as well. Therefore, the use of this extraction step will be pondered and more deeply studied in further research.

\subsection{Apatite and $\mathrm{CaCO}_{3}$ bound phosphorus ( $\mathrm{HCl}-\mathrm{P}$ )}

The three studied lakes are from volcanic origin and are soft-water lakes, with total hardness of $16.67 \mathrm{mg} \mathrm{l}^{-1}$, $9.08 \mathrm{mg}^{-1}$ and $4.53 \mathrm{mg}^{-1}$ for Furnas, Sete Cidades and Fogo lakes, respectively. Therefore, $\mathrm{Ca}$ and $\mathrm{Mg}$ are present in low concentrations in these waters (Table 1). This might be the reason why, in these lakes, the $\mathrm{HCl}-\mathrm{P}$ concentration is much lower than the NaOH-P fraction, when compared with other hard-water lakes that has hight $\mathrm{HCl}-\mathrm{P}$ concentrations (Gonsiorczyk et al., 1998; Kaiserli et al., 2002). Apatite- $\mathrm{P}$ (which is mainly extracted by $\mathrm{HCl}$ ) is assumed to be an inert fraction (Psenner and Pucsko, 1988). Thus, the $\mathrm{P}$ concentration in this extraction step will not be bio-available so easily, being considered permanent burial (Jin et al., 2006).

\subsection{Labile organic and refractory $\mathrm{P}\left(\mathrm{NaOH}-\mathrm{P}\right.$ at $\left.85^{\circ} \mathrm{C}\right)$}

This extraction step also seems to be an inert P-fraction resulting from soils, terrestrial plant material and dust, loaded into the lakes by inflows, wind and precipitation (Psenner and Pucsko, 1988). This is the main P pool in Fogo Lake. As demonstrated in Fig. 5, P contribution at Fogo lake increase from the first to the next extraction steps. This is desirable in terms of potential $\mathrm{P}$ release to the overlaying water, because it means that the higher $\mathrm{P}$ concentration pools are the most inert ones. So, the $\mathrm{P}$ release will not occur easily in this lake, preventing eutrophication. However, a question is proposed when looking to the results for the other two lakes (Fig. 5): is it possible that hot-NaOH-P pool would be partially transformed into $\mathrm{NaOH}-\mathrm{P}$ pool, by biological activity? If these two $\mathrm{P}$ pools can be biologically related, then this would explain why $\mathrm{NaOH}-\mathrm{P}$ pool is much higher than hot- $\mathrm{NaOH}-\mathrm{P}$ pool, for Furnas and Sete Cidades Lakes. This would also be a concern for the future trophic status of Lake Fogo. Therefore, more research in this area is needed.

\subsection{Phosphorus maximum solubilization potential}

The results, in Table 3, show that the P-MSP value in Fogo lake is higher in the most inert fraction $(\mathrm{NaOH}-$ SRP at $85^{\circ} \mathrm{C}$ ). Even for the more bio-available P-fractions (first and second extraction step), the P-MSP values are under 2. $\mu \mathrm{g} \mathrm{P} 1^{-1}$, which would not have any impact. In fact, the sum of all P-MSP values for the Fogo lake is $40 \mu \mathrm{g} \mathrm{P} 1^{-1}$.

On the other hand, looking at the P-MSP values for Furnas and Sete Cidades lake, algal bloom risk is evident. Although P-MSP is in relatively low concentration for the most bio-available $\mathrm{P}$ forms (under $13 \mu \mathrm{g} \mathrm{P}{ }^{-1}$ ), the P-MSP values for the $\mathrm{P}-\mathrm{NaOH}$ fraction are 182 and $38 \mu \mathrm{g} \mathrm{P} 1^{-1}$ for Furnas and Sete Cidades, respectively. Thus, it is expected that these two lakes could suffer a more intense eutrofication process in a short term.

\section{Acknowledgements}

The authors wish to thank the field expertise provided by Mr. José Gouveia and the comments provided by Dr. Dina Pacheco. The authors also acknowledge the Grant SFRH/BD/25653/2005 from the Foundation for Science 
and Technology/M.C.T., Portugal, awarded to Ribeiro, D.C.

\section{References}

APHA, AWWA, WPCF, 1995. Standard methods for the examination of water and wastewater.

Booth, B., Croasdale, R., Walker, G., 1978. A quantitative study of five thousand years of volcanism on São Miguel, Azores. Philos. Trans. Roy. Soc. Lond. 288, 271-319.

Cruz, J.V., França, Z., 2006. Hydrogeochemistry of thermal and mineral water springs of the Azores archipelago (Portugal). J. Volcanol. Geoth. Res. 151 (4), 382-398.

Golterman, H.L., 2001. Phosphate release from anoxic sediments or 'What did Mortimer really write?'. Hydrobiologia 450 (1-3), 99-106.

Gonsiorczyk, T., Casper, P., Koschel, R., 1998. Phosphorus-binding forms in the sediment of an oligotrophic and an eutrophic hardwater lake of the Baltic Lake District (Germany). Water Sci. Technol. 37 (3), $51-58$.

Jin, X., Wang, S., Pang, Y., Chang Wu, F., 2006. Phosphorus fractions and the effect of $\mathrm{pH}$ on the phosphorus release of the sediments from different trophic areas in Taihu Lake. China Environ. Pollut. 139 (2), 288-295.

Kaiserli, A., Voutsa, D., Samara, C., 2002. Phosphorus fractionation in lake sediments - Lakes Volvi and Koronia, N. Greece. Chemosphere 46 (8), 1147-1155.
Kim, L.H., Choi, E., Stenstrom, M.K., 2003. Sediment characteristics, phosphorus types and phosphorus release rates between river and lake sediments. Chemosphere 50 (1), 53-61.

Lijklema, L., Koelmans, A., Portielje, R., 1993. Water quality impacts of sediment pollution and the role of early diagenesis. Water Sci. Technol. 28 (8-9), 1-12.

Romero-Gonzalez, M.E., Zambrano, E., Mesa, J., Ledo de Medina, H., 2001. Fractional phosphate composition in sediments from a tropical river (Catatumbo River, Venezuela). Hydrobiologia.

Pettersson, K., Boström, B., Jacobsen, O., 1988. Phosphorus in Sediments - speciation and analysis. Hydrobiologia 170, 91-101.

Psenner, R., Pucsko, R., 1988. Phosphorus fractionation: advantages and limits of the method for the study of sediment $\mathrm{P}$ origins and interactions. Arch. Hydrobiol. Beih 30, 43-59.

Ramm, K., Scheps, V., 1997. Phosphorus balance of a polytrophic shallow lake with the consideration of phosphorus release. Hydrobiologia 342 $343(0), 43-53$.

Ruban, V., López-Sánchez, J.F., Pardo, P., Rauret, G., Muntau, H., Quevauviller, Ph., 1999. Selection and evaluation of sequential extraction procedures for the determination of phosphorus forms in lake sediment. J. Environ. Monitor. 1, 51-56.

Ruttenberg, K.C., 1992. Development of sequential extraction method for different forms of phosphorus in marine sediments. Limnol. Oceanogr. 37 (7), 1460-1482.

Zhou, Q., Gibson, C.E., Zhu, Y., 2001. Evaluation of phosphorus bioavailability in sediments of three contrasting lakes in China and the UK. Chemosphere 42 (2), 221-225. 